\title{
LAPORAN KEUANGAN
}

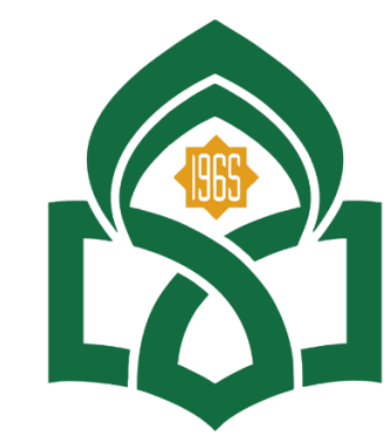

UNIVERSITAS ISLAM NEGER

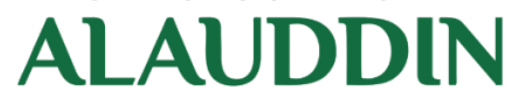

M A K A S S A R

\author{
Makalah \\ Disusun untuk Memenuhi Salah Satu Tugas \\ Mata Kuliah Kewirausahaan \\ Jurusan Perbankan Syariah \\ Dosen Pengampu :
}

Dra. Hj. Nuraeni Gani, M.M.

NIP: 196412111991032001

Disusun Oleh :

Tenri Qalby. S

NIM : 90500117091

\section{JURUSAN PERBANKAN SYARIAH \\ FAKULTASEKONOMI DAN BISNIS ISLAM \\ UNIVERSITAS ISLAM NEGERI ALAUDDIN MAKASSAR}




\section{KATA PENGANTAR}

Puji syukur kita panjatkan kehadirat Allah SWT atas segala rahmat-Nya sehingga makalah ini dapat tersusun sampai dengan selesai. Tidak lupa penulis mengucapkan terima kasih terhadap bantuan dari pihak yang telah berkontribusi dengan memberikan sumbangan baik pikiran maupun materinya.

Penulis sangat berharap semoga makalah ini dapat menambah pengetahuan serta pengalaman bagi pembacanya. Bahkan kami berharap lebih besar agar makalah ini bisa pembaca praktekkan dalam kehidupan sehari-hari ataupun dunia kerja.

Penulis sangat menyadari bahwa masih banyak kekurangan dalam penyusunan makalah ini karena keterbatasan pengetahuan dan pengalaman. Untuk itu penulis sangat mengharapkan kritik dan saran yang membangun dari pembaca demi kesempurnaan makalah ini.

Makassar, 19 Desember 2021

Penulis 


\section{DAFTAR ISI}

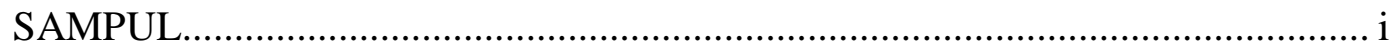

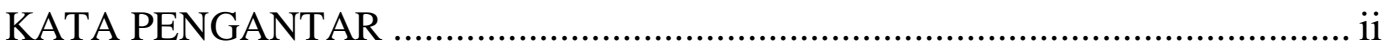

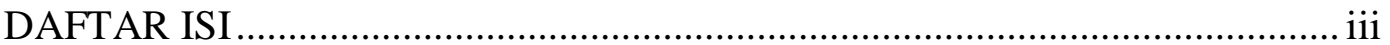

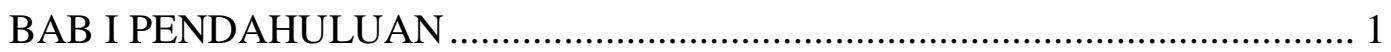

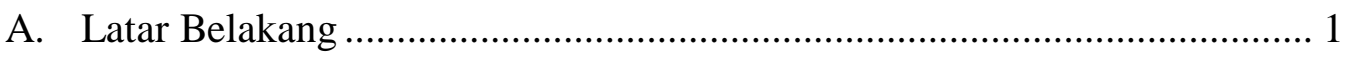

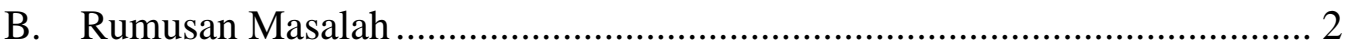

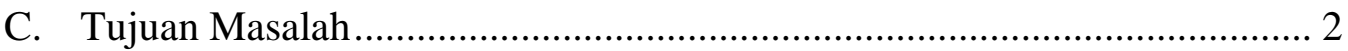

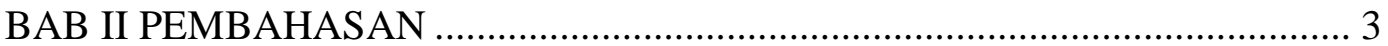

A. Pengertian Laporan Keuangan ................................................................. 3

B. Jenis-Jenis Laporan Keuangan .................................................................. 4

C. Fungsi Laporan Keuangan ........................................................................ 5

BAB III PENUTUP................................................................................ 7

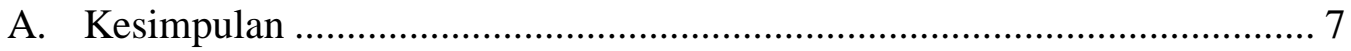

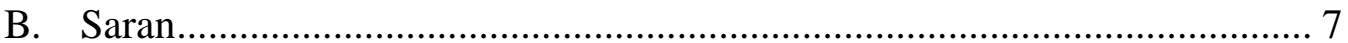

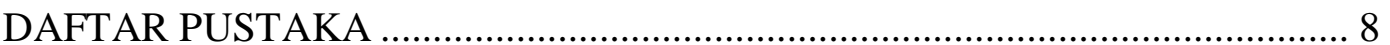




\section{BAB I \\ PENDAHULUAN}

\section{A. Latar Belakang}

Laporan keuangan sangat berperan penting dalam sebuah perusahaan. Hal ini dikarenakan laporan keuangan merupakan pondasi dalam menetapkan atau menilai posisi keuangan perusahaan. Pada dasarnya laporan keuanagan ialah hasil (output) yang didapatkan dari proses kegiatan akuntasi keuangan. Tentunya perusahaan ingin mengetahui kondiri terakhir keuangan dari perusahaannya di akhir priode tertentu bahkan sementara priode berjalan, seperti berapa profit yang di peroleh, berapa jumlah utang jangka pendek dan panjang dan lain sebagainya yang berkaitan dengan keuangan sebuah perusahaan.

Informasi dari laporan keuangan diharapkan dapat menjawab segala pertanyaan yang berkaitan tentang keuangan perusahaan seperti yang di atas atau sering disebut laporan keuangan (financial statement) perusahaan. Maka dari itu manajemen harus menyusun laporan keuangan, karena laporan keuangan merupakan tanggung jawab manajer kepada pemilik perusahaan.

Dengan melihat laporan keuangan perusahaan, pemilik perusahaan akan sangant mudah menilai kinerja dan keberhasilan manajemen dalam mengelola perusahaan. Takhanya itu laporan keuangan juga diperuntukkan memenuhi pihak-pihak lain yang berkepentingan untuk perusahaan tersebut, seperti pemerintah, pemodal dan lain sebagainya. 


\section{B. Rumusan Masalah}

1. Apa Pengertian Laporan Keuangan?

2. Apa saja Jenis-Jenis Laporan Keuangan?

3. Apa Fungsi dan Kegunaan Laporan Keuangan?

\section{Tujuan Masalah}

1. Mengetahui Pengertian Laporan Keuangan

2. Mengetahui Jenis-Jenis Laporan Keuangan

3. Mengetahui Fungsi dan Kegunaan Laporan Keuangan 


\section{BAB II \\ PEMBAHASAN}

\section{A. Pengertian Laporan Keuangan}

Dalam KBBI laporan keuangan adalah laporan mengenai data keuangan yang berasal dari pembukuan. Sedangkan dalam Standar Akuntansi Keuangan No. 1 Ikatan Akuntan Indonesia (Revisi 2009) menjelaskan bahwa, Laporan keuangan adalah suatu penyajian terstruktur dari posisi keuangan dan kinerja keuangan suatu entitas, yang bertujuan untuk memberikan informasi mengenai posisi keuangan, kinerja keuangan dan arus kas entitas yang bermanfaat bagi sebagian besar kalangan pengguna laporan dalam pembuatan keputusan ekonomi.

Menurut Kasmir (2013:7) Laporan keuangan adalah laporan tentang gambaran kondisi keuangan yang terdapat pada suatu perusahaan yang terjadi sekarang atau periode yang akan datang.

Menurut Sofyan Syafri (2009:4) mengemukakan bahwa laporan keuangan adalah suatu kondisi keuangan dan hasil usaha perusahaan pada saat tertentu atau jangka waktu tertentu.

Dari penjelasan diatas maka dapat kita simpilkan bahwa laporan keuangan perusahaan merupakan salah satu sumber informasi yang penting disamping informasi lain seperti informasi industri, kondisi perekonomian, pangsa pasar perusahaan, kualitas manajemen dan lain sebagainya. 


\section{B. Jenis-Jenis Laporan Keuangan}

Menurut Hery (2015) laporan keuangan terdiri atas komponenkomponen dibawah ini:

1. Laporan Laba Rugi (Income Statement) merupakan laporan yang sistematis yang berkaitan pendapatan dan beban sebuah perusahaan untuk periode atau waktu tertentu. Dalam laporan laba rugi terdapat informasi mengenai hasil kinerja manajemen atau hasil kegiatan operasional perusahaan, yaitu keuntungan dan kerugian bersih yang merupakan hasil dari pendapatan dan keuntungan dikurangi dengan beban dan kerugian.

2. Laporan Ekuitas Pemilik (Statement of Owner's Equity) adalah sebuah laporan yang menyajikan rankuman perubahan dalam ekuitas pemilik suatu perusahaan untuk satu periode atau waktu tertentu. Laporan ini sering dinamakan sebagai laporan perubahan modal.

3. Neraca (Balance Sheet) adalah sebuah laporan yang sistematis tentang posisi aset, kewajiban dan ekuitas perusahaan per tanggal tertentu. Tujuan dari laporan ini tidak lain adalah untuk menggambarkan posisi keuangan perusahaan.

4. Laporan Arus Kas (Statement of Cash Flows) adalah sebuah laporan yang menggambarkan arus kas masuk dan arus kas keluar secara terperinci dari masing-masing aktivitas, yaitu mulai dari aktivitas operasi, aktivitas investasi sampai pada aktivitas pendanaan atau pembiayaan untuk satu periode waktu tertentu. Laporan arus kas menunjukkan besarnya kenaikan/penurunan bersih kas dari seluruh aktivitas selama periode 
berjalan serta saldo kas yang dimiliki perusahaan sampai dengan akhir periode.

\section{Fungsi Laporan Keuangan}

Menurut Kasmir (2013:10) secara umum laporan keuangan bertujuan untuk memberikan informasi keuangan suatu perusahaan, baik pada saat tertentu ataupun periode tertentu. Lebih Jelasnya laporan keuangan dapat memberikan informasi keuangan kepada pihak-pihak tertentu yang memiliki kepentingan di perusahaan. Kasmir (2013:11), membagi tujuan pembuatan laporan keuangan menjadi 8, yaitu:

1. Memberikan informasi tentang jenis dan jumlah aktiva lancar ataupun tetap yang dimiliki perusahaan pada saat ini;

2. Memberikan informasi tentang jenis dan jumlah kewajiban dan modal yang dimiliki perusahaan pada saat ini;

3. Memberikan informasi tentang jenis dan jumlah pendapatan yang diperolehpada saat periode tertentu;

4. Memberikan informasi tentang jumlah biaya dan jenis biaya yang dikeluarkan perusahaan dalam suatu periode tertentu;

5. Memberikan informasi tentang perubahan-perubahan yang terjadi terhadap aktiva, pasiva, dan modal perusahaan;

6. Memberikan informasi tentang kinerja manajemen perusahaan dalam suatu periode;

7. Memberikan informasi tentang catatan-catatan atas laporan keuangan;

8. Informasi keuangan lainnya. 
Menurut Ikatan Akuntansi Indonesia (2009:3), laporan keuangan bertujuan untuk menyiapkan informasi yang berkaitan tentang posisi keuangan, kinerja, serta perubahan posisi keuangan suatu perusahaan yang bermanfaat bagi sejumlah besar pemakai dalam pengambilan keputusan ekonomi. 


\section{BAB III \\ PENUTUP}

\section{A. Kesimpulan}

Dalam KBBI laporan keuangan adalah laporan mengenai data keuangan yang berasal dari pembukuan. Sedangkan dalam Standar Akuntansi Keuangan No. 1 Ikatan Akuntan Indonesia (Revisi 2009) menjelaskan bahwa, Laporan keuangan adalah suatu penyajian terstruktur dari posisi keuangan dan kinerja keuangan suatu entitas, yang bertujuan untuk memberikan informasi mengenai posisi keuangan, kinerja keuangan dan arus kas entitas yang bermanfaat bagi sebagian besar kalangan pengguna laporan dalam pembuatan keputusan ekonomi.

laporan keuangan terdiri atas komponen-komponen, yaitu: Laporan Laba Rugi, Laporan Ekuitas Pemilik, Neraca dan Laporan Arus Kas.

laporan keuangan bertujuan untuk menyiapkan informasi yang berkaitan tentang posisi keuangan, kinerja, serta perubahan posisi keuangan suatu perusahaan yang bermanfaat bagi sejumlah besar pemakai dalam pengambilan keputusan ekonomi.

\section{B. Saran}

Karena amat pentingnya mengetahui laporan keuangan ini maka penulis menyarankan agar semua elemen dalam organisasi dapat mempelajari laporan keuangan ini agar tercipta seebuah perusahaan yang sehat dan dapat berkembang sepanjang zaman. 


\section{DAFTAR PUSTAKA}

Kasmir. Analisis Laporan Keuangan. Jakarta: PT Raja Grafindo Persada, 2013.

Kemdikbud. KBBI daring. https://kbbi.kemdikbud.go.id/entri/laporan\%20 keuangan (19 Desember 2021).

Ikatan Akuntan Indonesia. Pernyataan Standar Keuangan 01 : Penyajian Laporan Keuangan (Revisi 2009). Jakarta : IAI, 2009.

Harahap, Sofyan Syafri. Analisis Kritis Atas Laporan Keuangan. Jakarta: Raja Grafindo Persada, 2009.

Hery. Pengantar Akuntansi: Comprehensive Edition, Jakarta: Grasindo, 2015. 